\title{
Mindre inkontinens ved vektreduksjon etter fødsel
}

\author{
Vektreduksjon etter fødsel beskytter \\ mot urininkontinens, mens vektopp- \\ gang under svangerskapet har liten \\ klinisk betydning.
}

Kvinners kroppsmasseindeks er en viktig risikofaktor for urininkontinens. Vektøkning under svangerskapet har vært mistenkt å være en viktig årsaksfaktor for urininkontinens under og etter et svangerskap. Vitenskapelig dokumentasjon har imidlertid manglet.

Vi har undersøkt risikoen for urininkontinens under svangerskapet og seks måneder postpartum med data fra Den norske mor og barn-undersøkelsen (1). Studien omfattet 12679 førstegangsfødende kvinner som var kontinente før svangerskapet.

Vektøkning over 50-prosentilen i uke $0-15$ i svangerskapet var assosiert med økt risiko for urininkontinens under svangerskapet, mens vektoppgang $\mathrm{i}$ andre deler av svangerskapet ikke hadde betydning. Vektoppgang under svangerskapet var ikke assosiert med økt risiko for urininkontinens seks måneder etter fødsel. Hvis kvinnen seks måneder etter fødsel ikke hadde gjenvunnet den vekten hun hadde like før hun ble gravid, økte imidlertid risikoen for urininkontinens.

For hver kilo vektreduksjon i de første seks månedene etter fødsel blant kvinner som var inkontinent under svangerskapet, sank relativ risiko for urininkontinens med $2,1 \%$ (RR 0,98; $95 \%$ KI 0,97-0,99). Også forekomsten av nyoppstått urininkontinens før seks måneder etter fødsel sank med økende vektreduksjon etter fødsel.

Kvinner bør få informasjon under og etter svangerskap om at vektreduksjon etter fødsel kan forebygge urininkontinens.

\section{Stian Langeland Wesnes}

stian.langeland@isf.uib.no

Universitetet i Bergen

\section{Litteratur}

1. Wesnes SL, Hunskaar S, Bo K et al. Urinary incontinence and weight change during pregnancy and post partum: a cohort study. Am J Epidemiol 2010 e-publisert 20.8.2010.

\section{Jernmangelanemi i Sørøst-Asia}

Jernmangelanemi er vanlig blant barn i Sørøst-Asia, men jerntilskudd og pro-/prebiotika kan redusere forekomsten.

I India er over $75 \%$ av alle småbarn anemiske. En tverrsnittsstudie av 401 presumptivt friske indiske barn i alderen 12-23 måneder fra rurale strøk viste assosiasjon mellom anemi og hhv. hemoglobinopatier, folatmangel, maternell anemi, og familiens $ø$ konomi og mattilgang (1). Sterkest assosiasjon var det imidlertid med jernmangel, målt med lavt ferritinnivå. Vedvarende amming disponerte for jernmangel. I tillegg til anemi vil jernmangel kunne føre til manglende fysisk og kognitiv utvikling.

I en indonesisk studie av 81885 familier i rurale strøk og 26653 familier fra urban slum fant man lavere forekomst av anemi blant barna (6-59 måneder) hvis de fikk jernberiket melk. Resultatene var sammenliknbare i rurale og urbane områder (OR hhv. 0,76 og 0,79, p<0,0001) (2). Man kunne ikke påvise en tilsvarende effekt av jernberikede nudler, men kombinasjonen av beriket melk og nudler var bedre enn beriket melk alene.

En annen lovende strategi kan være å påvirke tarmfloraen. En randomisert dobbeltblind studie fra New Dehli i India viste at 1-4 år gamle barn som fikk melk tilsatt probiotika (Bifidobacterium lactis) og prebiotika (oligosakkarid) i ett år hadde risikoreduksjon på $45 \%$ (95\% KI 11-66\%, $p=0,01)$ for jernmangel og anemi, sammenliknet med barn som fikk samme melk, men uten tilsetninger (3). Det var også en positiv effekt på veksten.

\section{Kristoffer Brodwall}

kristoffer.brodwall@gmail.com

Barneavdelinga

Ålesund sjukehus

Litteratur

1. Pasricha SR, Black J, Muthayya S et al. Determinants of anemia among young children in rural India. Pediatrics 2010: 126: e140-9.

2. Semba RD, Moench-Pfanner R, Sun K et al. Ironfortified milk and noodle consumption is associated with lower risk of anemia among children aged 6-59 mo in Indonesia. Am J Clin Nutr 2010; 92: $170-6$.

3. Sazawal S, Dhingra U, Hiremath $G$ et al. Effects of Bifidobacterium lactis HNO19 and prebiotic oligosaccharide added to milk on iron status, anemia, and growth among children 1 to 4 years old. J Pediatr Gastroenterol Nutr 2010; 51: 341-6.

\section{Kun bryst- kompresjon ved hjertestans}

\author{
Brystkompresjoner alene kan \\ være godt nok ved hjertestans. \\ Dette viser to nye randomiserte \\ studier.
}

I en svensk prospektiv randomisert studie ble 1276 pasienter med mistanke om hjertestans inkludert (1). Pasientene ble behandlet av privatpersoner som hadde ringt nødtelefonen og der fått veiledning av spesialutdannet helsepersonell. Pasientene ble randomisert til å motta enten standard hjerte-lungeredning eller kun hjertekompresjoner.

Overlevelsen etter 30 dager var like god i begge grupper; $8,7 \%$ i gruppen som kun fikk hjertekompresjoner og 7,0\% i gruppen som fikk standard hjertelunge-redning. En amerikansk-engelsk studie viste tilsvarende resultater (2).

- Disse studiene bekrefter resultater fra ikke-randomiserte studier, blant annet fra Norge, sier professor Petter Andreas Steen ved Oslo universitetssykehus. Ved kardial årsak til hjertestans betyr kanskje ikke munn-til-munn så mye, i hvert fall ikke ved telefoninstruksjon i hjerte-lunge-redning.

- Disse studiene innebærer imidlertid ikke at vi kan glemme opplæring i munntil-munn-metoden, sier Steen. Resultatene kan delvis skyldes at det er vanskelig å instruere i munn-til-munnmetoden via telefon. Viktigere er det at hjertestans hos de fleste barn og hos ca. en tredel av voksne ikke har kardiale årsaker, men skyldes manglende ventilasjon. I slike tilfeller er resultatet mye dårligere uten munn-til-munn. Det er også viktig at $\mathrm{i}$ land utenom Europa og Nord-Amerika har de fleste hjertestans ikke-kardiale årsaker, slik som drukning, ulykker eller fødselsasfyksi.

I Norge instruerer nok de fleste AMKsentraler nå bare i hjertekompresjoner ved hjertestans med sannsynlig kardial årsak hos voksne pasienter, mens opplæring i hjerte-lunge-redning også omfatter munn-til-munn, sier Steen.

\section{Eline Feiring}

eline.feiring@legeforeningen.no

Tidsskriftet

\section{Litteratur}

1. Svensson L, Bohm K, Castrén M et al. Compression-only CPR or standard CPR in out-ofhospital cardiac arrest. N Engl J Med 2010; 363: $434-42$

2. Rea TD, Fahrenbruch C, Culley L et al. CPR with chest compression alone or with rescue breathing. N Engl J Med 2010; 363: 423-33. 